\title{
Exploration on the Black Humor in American Literature
}

\author{
Yan Huang \\ East China Jiaotong University, Nanchang, 330013, China
}

\author{
Key words: Black humor, Joseph Heller, Artistic features
}

\begin{abstract}
The black humor in American literature received extensive attention of scholars and writers. Because its unique artistic characteristics and artistic charm make it not only become a huge development in the literature, also make readers rethink from the perspective of social and historical reflection in the process of reading. This article analyzes the artistic characteristic of Joseph Heller's representative work Catch 22 and expresses the important role of the black humor in American literature in the expression of human emotions.
\end{abstract}

\section{Introduction}

"Black humor" is a modernist literary genre, and it originated in America in the $1960 \mathrm{~s}$. It gets its name from the American writer Friedman's collection of "black humor", and became a popular kind of literature genre and affected the development of American literature. The "black" in the English language symbolizes darkness, depression, and death. And black humor, however, means that this is not the humor in the traditional sense. It doesn't have a relaxed and happy mood, while it is very desperate and it is the humor in a difficult situation and under the gallows of western society. In concrete works of black humor, writers tend to descript some "Anti-heroes" with abnormal behaviors and reflect social reality through their bizarre behaviors. To some extent, it shows the author's thinking and main ideas about social problems. As for the concrete description technique they will break the tradition and ignore the logic of the story. Connect the reality, dreams and memories together, and mix serious philosophical with playful banter. For example, Joseph Heller's "Catch 22" uses the black humor, and fully shows the American social reality, and attacked the absurd reality and chaos of society.

\section{The cause of black humor in American literature}

In the 1960s, after World War II, the United States was involved in the morass of the Vietnam War. The lost in fighting and the heavy casualties made the whole America in a turbulent environment. The society was in chaos. This chaos made the whole nation in a state of panic. American life in this period was in panic and fear. In such a social background, the authors observed the phenomenon, through their keen social observation and extreme attitude to survey the society at that time. Although writers could capture the various problems in American society, through their own strength, it was very difficult to affect the whole society ${ }^{[1]}$. Therefore, they can only use self-mockery and pathological form to express their discontent, anger and fear for the inability to change the status quo.

Black humor in American literature is, as it were, catalyzed by the social background of confusion and upheaval. In the process of creation, the writers applied existentialism philosophy such as nothing, alienation and absurdity to literary creation. Unlike traditional literary creation, black humor writers showed more negative and pessimistic point of views in their works. They think personal choice of positive action is difficult to success. When facing the bizarre phenomenon, people can only emit helpless wry smile, and are unable to change the status quo. Only with this can they relieve their pain.

The concept of black humor appeared in American famous writer and literary critic Friedman's selected portfolio in 1965, named "black humor". In traditional English literature, black often represents the darkness, obscure and death. When humor is black, it means that the humor has the differences between the traditional one. It might have lost its traditional sense of humor that brings 
people pleasant feeling, more is the humor under gallows, helpless and desperate humor. The works in this anthology created anti-hero images. Their behaviors and words are funny, but through these ridiculous words and deeds, the real phenomenon is reflected, which often contains the writer's own opinion. In these works, the style of the novel is also different from the previous literature, the writer doesn't make the narration in accordance with the time sequence or a certain clue, but usually connect bizarre fantasies with memories of the past in the narrative of real life, and connect serious philosophical question discussion with people's ridicule to reflect on all kinds of phenomena in society ${ }^{[2]}$.

\section{The artistic features of American black humor literature - "Catch 22 "as an example}

Representative of the American black fiction writer, Heller, has other types of work, but his main works are black humor novels, and his representative work is the famous "Catch 22 "."Catch 22 " was published in 1961. At the beginning of the publication, it didn't cause great repercussions. But with the outbreak and expansion of the war in Vietnam, America people fermented an anti-war thought, and the novel is in the subject of the anti-war thought. Thus it drew wide attention of the American people. Some readers comment it as "brutal and sound", some other evaluate it as "thrilling comedy ", even some evaluate it has the same effect on irony as Rabelais's novel.

The content Catch 22 describes doesn't exist in real life. As described in the fiction: "Here is only one trap which is Catch 22." Catch 22 regulates that when a soldier faces the real danger in the battlefield, if he can still expressed concern about the safety of his own, it means that the phenomenon is the result that soldiers had of the rational activities. The hero Orr is crazy. In accordance with the relevant regulations and policies, he is allowed to stop flying work, as long as he himself to ask for it. But according to Catch 22, when Orr puts forward this request it proves that he can make rational thinking, and the spirit is normal. He still has to go to war and perform flight mission. Therefore, Catch 22 that doesn't exist at all makes use of the mandatory of catch, makes the human into the trap of war. The catch that doesn't exist also implies a dilemma that human can not get rid of and fully embodies the artistic features of black humor literature in American literature ${ }^{[3]}$.

\section{The narrative structure subverts the traditional novels}

If we evaluate Catch 22 according to the artistic criteria of traditional literary form, structurally the Catch 22 does not have the basic narrative structure. This is one of the artistic features of black humor literature. The author did not adopt the structure of the traditional novel writing, but opened up two clues in the fiction. One clue is Marlow as the center according to the order of time; the other clue is the disordered psychology of Yossarian. At the same time, because the two clues in context often cross, it makes readers feel chaos in the process of reading. The author describes and reflects the absurdity and chaos of society at that time by the way of disorganized prose structure. The chaotic society makes the author think that society has lost its basic operation order. In this way social reality can be better reflected s so as to inspire readers to reflect.

\section{Anti-logical Plot}

As for the plot of normal novels, a detailed description of ins and outs of the story is usually done. The causes and effects with the strong logic plot should be the normal prose structure form of a novel, but in black humor novels the principle of literary creation does not strictly be abided by. In the process of their writing, writing is not based on a clue or a certain time sequence. In the narrative of Catch 22, the plot and story description are ridiculous and can not be traced in real life. They are with great irrationality and hard for people to understand, even with some distortion of human nature in the plot. For example, the description of Doctor Daniel is full of absurdity and irony. Daniel is very greedy. In order to obtain extra subsidies, no matter he is involved in attendance or not, he will add his name in the flight team list, which gives him a lot of benefits ${ }^{[4]}$.In one mission, the plane crashed, and the crew of the flight were all gone, which also includes his name. So he has always been regarded as a person who has been killed. Though he lives healthily, colleagues and family around him saw him 
living actively, all of the files, materials and newspapers regard him as a man who has been killed in an airplane crash. In contrary to his situation, a comrade of Yossarian is missed in the rank list. Although he has already died in the war, his sacrifice was not recognized. Thus it can be seen that in this circle, the living will be regarded as the dead, while the dead enjoy the living treat. The absurdity of the social reality it describes is performed incisively and vividly, and it hits the nail on the head.

\section{Break the traditional rules of language}

Black humor in American literature usually expresses dissatisfaction against reality through informal language. Catch 22 tries to express the boring and serious issue in a fun way of language. Although the expression of the characters in the novel is funny, and cynicism and playful tone is usually adopted, profound philosophy is in the words. The author will express solemn sacred things with very strange language and imply trivial thing in life in a very solemn sacred language environment ${ }^{[5]}$. For example, the author quotes the language of the joke to tell the painful death, and express despair in a very humorous language. On one hand, it can reduce the serious feeling; on the other hand it also shows the frustration of character in the face of the phenomenon and they are unable to change it. In concrete works conflicting language often is connected to form a ridiculous and grotesque form and suggests a kind of social reality that people cannot understand. It is this language form of permutation and combination that breaks the traditional method of language rules makes readers produce a feeling of strangeness and weirdness in the process of reading and meditate with the society. In addition, the language of the characters is also very funny. It is not only sloppy, and is not logical even insane. If the dialogue and language of the characters are in the specific social reality, it is completely unable to communicate and meaningless. Only in certain literature environment, such language which breaks traditional rules has certain significance.

\section{Character of "anti-hero" type}

In traditional American literary creation, a hero image which saves people in distress and danger will usually be created. These images of heroes are great and tall, which leads to the strong hero complex in American literature. However, in black humor novels, the authors tend to create some "anti-heroes". These anti-heroes are different from Joyce's "non hero" image, and are also different with Kafka's "weak hero" image. In the traditional creation of "anti-hero" image, its essence is to express its resistance and rebellious spirit to the serious distortion and deformation of the social phenomenon. They are able to use a negative attitude different from the hero to make silent resistance against the society. As for its essence, it is a kind of hero activity, and is more robust than the typical hero image and clearer. "Anti-hero" in the black humor also exist some differences in character creation ${ }^{[6]}$. In Catch 22, protagonist Yossarian and military doctor Daniel are created. The common feature of these characters is "anti-hero" image. With applying the theatrical expression forms the author Heller makes statements of implied tragic connotation, and also applied the exaggeration and caricatures of writing to depict characters. The characters in the novel are distinct with language features. The whole article presents a sense of humor and depth, and a playful and serious style.

\section{Conclusion}

To sum up, the occurrence of black humor in American literature makes new atmosphere in emotional patterns in the literature. By the absurd form of expression, black humor dissolves the funny features in the traditional humor. Its absurdity it contains also effectively dissolved the depression and the seriousness in the traditional tragedy. Through depicting the despairing image and plot, it dispels the entertainment of traditional comedy. The tragic smile and brave struggling of the characters replace the sense of pain that tragedy brings. Black humor uses the laughter to express tragedy and tragic fate, describes the tragic plot in the absurd form. It creates new literature from which is different from the traditional tragedy literature and drama literature form. Black humor is the product of the development of modern American literature, and is also the important milestone in the 
development of modern literature. With the continuous development of black humor, modern American literature has made great progress and development, too.

\section{References}

[1] Li Peiyan. Analysis on the traditional humor and black humor art of American literature. Journal of Writer, 2013 (2)

[2] Yang Li. Value orientation of contemporary Chinese novels under the influence of American black humor literature. Journal of Chang 'an University (social science edition), 2013 (6)

[3] Hu Tiesheng, Xia Wenjing. The uncertainty features of postmodern literature - the black humor narrative strategy of Catch 22 catch as an example. Social Science Journal of Jilin University, $2015(2)$

[4] Chang Zhi-yong. Historical value and cultural significance of American black humor literature. Journal of Huaihai Technology Institute (social science edition), 2012 (5)

[5] Zhu Gang. American humor and Americanness--a review of Su Hui's "black humor and humor tradition of American novels. Foreign literature research, 2013 (6)

[6] Cai Jian-ping. Analysis on the use of black humor and its artistic features in American film "Catch 22". The movie review, 2015, (8) : 45-46. 